\title{
STUDIES ON A PROTEOLYTIC ENZYME SYSTEM OF THE BLOOD. II. FIBRINOLYSOKINASE ACTIVATORS FOR PROFIBRINOLYSIN ${ }^{1}$
}

\author{
By JESSICA H. LEWIS AND JOHN H. FERGUSON with the tech NiCAL ASSISTANCE of \\ ANN C. HOWE AND JANE ROGERS
}

\author{
(From the Department of Physiology, University of North Carolina, Chapel Hill)
}

(Submitted for publication March 3, 1950; accepted, May 8, 1950)

Fleisher and Loeb (1), in 1915, described fibrinolysis of plasma clots (rabbit, cat, guineapig) during aseptic contact with fragments of various animal tissues. Their assumption that this fibrinolysis was simply due to a tissue proteolytic enzyme may be questioned in the light of more modern work on fibrinolytic mechanisms. In particular, Christensen $(2,3)$, following the earlier lead of Milstone (4), clearly showed that plasma contains a precursor (plasminogen or profibrinolysin) which, in the human, can be activated to a fibrinolytic enzyme by streptokinase. "Fibrinokinase" substances from various tissues have been described by Astrup and Permin (5) and Permin (6). Tagnon and Petermann (7) recently fractionated rat lung tissue by differential centrifugation, following the principles established by Claude (8), and found kinase activity in the particulate (notably "microsome") fraction and inhibitor in the supernate.

Our own studies employ similar methods of tissue fractionation, applied, in the first place, to an extensive survey of dog tissue fractions, with testing for fibrinolysokinase activity on dog serum profibrinolysin. Previous studies of bacterial activators (9), streptokinase (10) and staphylokinase $(11,12)$ emphasize species variability in the susceptibility of prolysins to bacterial lysokinases, suggesting the need for similar comparative studies with tissue lysokinases. Having found certain lung preparations among the most active (cf. Tagnon and Petermann [13]) for dog prolysin, we have, in this study, tested lung fractions from eight species on prolysins from three (dog, human, bovine). In testing for fibrinolysokinase activity some important technical considerations of the

1 This investigation was supported by a research grant from the Division of Research Grants and Fellowships of the National Institutes of Health, U. S. Public Health Service. assay method have needed investigation. Since factors, in particular the thromboplastic protein described by Chargaff (14), modifying bloodclotting reactions are noted in tissue preparations, some preliminary tests of these have been made with our tissue fractions, including an experimental separation of fibrinolysokinase from thromboplastic activity.

\section{MATERIALS}

Materials used in our standard assay procedures for fibrinolysin and antifibrinolysin, viz., borate buffer, $\mathrm{pH}=$ 7.7; thrombin; "fibrinogen" (BF: Armour's bovine plasma fraction-I) ; and dog serum fibrinolysin, are fully described in the first paper of this series (15).

Profibrinolysin (prolysin): Recalcified hemoglobin-free oxalated plasma, defibrinated in bottles with the aid of glass rods and a mechanical shaker, gave a good yield of clear serum, which was cooled to $0^{\circ} \mathrm{C}$., brought to onethird saturation with ammonium sulfate (saturated solution at $0^{\circ}$ C.) and kept at zero temperature for 30-60 minutes. The precipitate, recovered by centrifugation, was dissolved in distilled water and dialyzed 18 hours against cold running tap water $\left(4^{\circ} \mathrm{C}\right.$.). The final precipitate, redissolved in borate buffer to one-fourth the original serum volume (corrected for diluents), contained most of the prolysin, very little active lysin, and no demonstrable antilysin. It was used immediately or stored at $-20^{\circ} \mathrm{C}$.

Saline-phosphate buffer: 0.85 per cent sodium chloride, buffered at $\mathrm{pH}=7.3$ with $0.0025 M$ phosphate, was used for tissue extractions.

Fibrinolysokinase (lysokinase), tissue fractions: Under nembutal anesthesia, animals were exsanguinated and the various tissues dissected out as free as possible from fat and connective tissue, washed with saline-buffer, drained on filter paper, and the (wet) weight recorded. Perfusion with cold saline-buffer in situ (brain) or isolated (other organs) removed practically all the blood from brain, lungs, liver, and kidney, but left some residual blood in the spleen. A $10 \mathrm{gm}$ piece of the larger organs, or as much as possible of the smaller tissues, was rapidly macerated in a Waring blendor with frozen saline-buffer, then passed through a $1 \mathrm{~mm}$ sieve, and thoroughly reground with pestle and mortar. The smallest specimens were cut up and ground directly in the chilled 
mortar. The mixture of tissue pulp plus saline-buffer was further diluted to $40 \mathrm{ml}$ (or proportionately) and subjected to differential centrifugation (see below). Each sedimented fraction was washed three times with saline-buffer, recentrifuging as before, and finally suspended in the diluent to volume $(\mathrm{ml})$ equal to original specimen weight $(\mathrm{gm})$.

As $2 \mathrm{ml}$ of each fraction were needed for testing, it was necessary to dilute fractions of pituitary $(0.044 \mathrm{gm})$, adrenal cortex $(1.0 \mathrm{gm})$, adrenal medulla (scraped from two dog adrenals), rib bone-marrow (1.86 gm), ureter $(1.0 \mathrm{gm})$, leucocytes $(0.25 \mathrm{ml}$ "cream" packed from 800 $\mathrm{ml}$ blood), and platelets (packed from $100 \mathrm{ml}$ plasma and microscopically free from corpuscles). "Fractionation" of some of the tissues (see Table I) frequently produced only certain of the sedimented fractions.

Differential centrifugation employed 1.) refrigerated International Centrifuge, Model PR-1; 2.) Servall High Speed Vacuum Centrifuge, Type SS-2.

Fraction I: the diluted tissue pulp (see above) was spun in $50 \mathrm{ml}$ tubes at $2500 \mathrm{rpm}(1900 \mathrm{~g})$ for three minutes, typically separating two layers of sediment, the bottom (Fraction I) consisting of gross particles, connective tissue, and large cellular fragments.

Fraction II: the fine layer on the surface of I, described by Claude (8) as consisting largely of cell nuclei.

Fractions $I I I-A$ and $I I I-B$ : the respective sediments in two successive recentrifugations of the supernatant, again at $2500 \mathrm{rpm}$ for three minutes each. These were small in volume.

Fraction IV: corresponding to Claude's "large granules," was the granular sediment obtained from the preceding supernatant by 30 minutes centrifugation at 3500 rpm $(2700 \mathrm{~g})$.

Fraction $V$ : was a small additional precipitate obtained on repeating the preceding centrifugation on the supernatant from IV.

Fraction VI: corresponding to Claude's "microsomes," was the small sediment, usually homogenous in appearance and often amber-colored, obtained by very highspeed centrifugation (up to $17,000 \mathrm{rpm}: 48,000 \mathrm{~g}$ ) of the preceding supernatant, for 90 minutes.

Fraction VII: the final supernatant, was typically a clear fluid, sometimes colored perhaps with a trace of hemoglobin.

A single lung fraction, called $(I V+V I)$, was used in later experiments. It was prepared by macerating the perfused lung in a Waring blendor, straining to remove fibrous tissue, cartilage, etc., and centrifuging for 15 minutes at $2500 \mathrm{rpm}$, discarding the sediment. The supernatant was then recentrifuged at $20,000 \mathrm{~g}$ for 90 minutes, the sediment collected as a single fraction, washed, and, employing the Waring blendor, suspended in a volume ( $\mathrm{ml}$ ) of saline buffer equal to one-half the original lung weight $(\mathrm{gm})$.

\section{METHODS}

Fibrinolysin (lysin) assay: Within definable experimental limits, the fibrinolysin concentration may be kept constant and the fibrinogen (fibrin) concentration varied to give lysis times which are inversely proportional to the fibrinogen concentration $(15,16)$. We have recently employed this principle to extend the range of sensitivity of our lysin assay method (15) by simply varying the fibrin concentration in the standard clot. Choosing 0.2 and 1.0 per cent clots ("per cent" referring to the dry weight of $\mathrm{BF}$ [see reagents] in the $0.5 \mathrm{ml}$ "fibrinogen" solution used in the standard clot), permits an assayable range of lysin units from 1-300. If a 100 unit lysin, which completes dissolution of the 1.0 per cent clot in five minutes, is diluted to 20 units, it will lyse the 0.2 per cent clot in five minutes also, and the points of a single standard reference curve (cf. 15), plotting lytic units against lysis times, hold both for a dilution series of original lysin tested on 1.0 per cent clots and for a parallel series of diluted lysin tested on 0.2 per cent clots, as shown by the data in Figure 1. However, when a similar comparison was made between the two strengths of clot using prolysin-fibrinolysokinase mixtures instead of fully activated fibrinolysin, some deviations occurred, in all probability (see below) due to activation of a prolysin contaminant of the $\mathrm{BF}$, which differs, of course, with the clot dilution. Hence, for comparative assays of various tissue preparations, the same substrate, usually 0.2 per cent clots, was used throughout.

Fibrinolysokinase (lysokinase) assay: In order to obtain maximum fibrinolysokinase effects, it has been found necessary to employ as the profibrinolysin a dog serum fraction (see Materials) free from antifibrinolysin and with minimal spontaneous activity, under the test conditions, but able to yield a potent fibrinolysin in preliminary tests with staphylokinase activator. Activation of prolysin by tissue kinases requires considerable time and is complicated by deterioration of the formed lysin. At $37^{\circ} \mathrm{C}$., the rapidity of activation may be offset by the subsequent lysin deterioration, while at $4^{\circ} \mathrm{C}$., activation

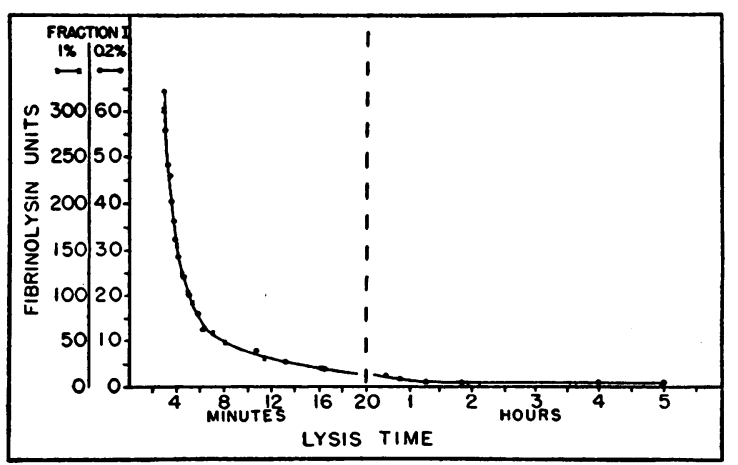

Fig. 1. Lysis Times of 1 Per Cent and 0.2 Per Cent Clots

$2.2 \mathrm{ml}$ of clotting mixture contained 1) $0.5 \mathrm{ml} 1$ per cent bovine fraction $\mathrm{I}(\mathrm{x}-\mathrm{x})$ and $0.5 \mathrm{ml}$ dilutions of full-strength dog fibrinolysin; 2) $0.5 \mathrm{ml} 0.2$ per cent BF $(-)$ and $0.5 \mathrm{ml}$ dilutions of one-fifth strength enzyme. 


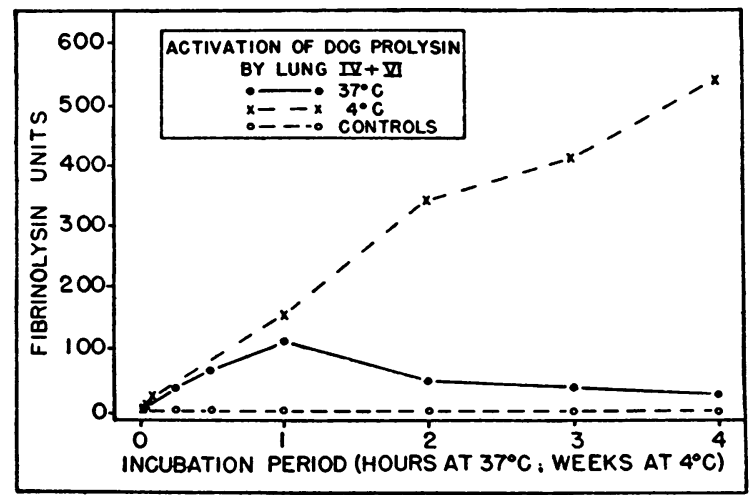

Fig. 2. Temperature Effects on Activation of Dog Prolysin by Dog Lung Fibrinolysokinase

is very much slower (see Figure 2) but deterioration is almost completely prevented, resulting in larger yields of lysin and more significant "maxima." These considerations led us to accept a compromise most suited to the particular experiment and the incubation conditions are therefore explicitly stated in each case. In actual practice, three mixtures: 1) $0.5 \mathrm{ml}$ prolysin + $0.5 \mathrm{ml}$ tissue fraction, 2) $0.5 \mathrm{ml}$ prolysin $+0.5 \mathrm{ml}$ salinebuffer, 3) $0.5 \mathrm{ml}$ tissue fraction $+0.5 \mathrm{ml}$ borate buffer, were incubated (as stated) and then tested for time of lysis when added to the standard clot. Controls 2) were negative or negligible $(<0.5$ unit), while controls 3 ) frequently showed some minor lytic activity especially with the more active tissue kinases (see below).

Cause of lytic activity in tissue fractions: The traces of lytic activity in the tissue controls (without added prolysin) might suggest three possibilities: 1) that the tissue fractions contain active lysin as well as lysokinase, 2) that active lysin (apart from kinase) might activate prolysin through some "autocatalytic" mechanism, or 3) that the bovine "fibrinogen," used for the test clots, may be contaminated with some prolysin which may react with tissue lysokinases even though bacterial fibrinolysokinases fail (9). The first possibility cannot be wholly ruled out pending the preparation of a clot substrate which is completely free from prolysin, as shown by a negative test becoming positive only when a known prolysin is added. There is no doubt about the inability of bacterial kinases to act in the absence of prolysin. We have therefore taken plasma from dogs (a suitable species) and attempted to prepare a "fibrinogen" which shows no fibrinolysin formation on treatment with staphylokinase. However, the following procedures were unsuccessful : 1) Ten to 12 reprecipitations at 25 per cent saturation with ammonium sulfate $(4) ; 2$ ) freezing and recovery of the cold-precipitable fibrinogen $(17)$; 3 ) adsorption with $\mathrm{BaSO}_{4}, \mathrm{BaCO}_{3}, \mathrm{Ca}_{3} \mathrm{P}_{2} \mathrm{O}_{8}$, asbestos, and charcoal. These studies are continuing but, until we obtain a more satisfactory substrate, we are proceeding with the use of bovine plasma fraction I (partially purified fibrinogen) in our investigations on fibrinolysis and deferring the final answer to the tissue protease ques- tion. The second possibility will be considered more fully in a later communication, but it may be stated that a number of experiments have failed to yield any evidence of "autocatalytic" lysin formation in mixtures containing both active enzyme and the prolysin. The third possibility is considered the most likely and novel and receives support from the following (Figure 3 ):

A 4 per cent solution of $\mathrm{BF}$ was clotted with 100 units of bovine thrombin and the "serum" (BFS) expressed and used in the following tests: I) BFS + fraction $(I V+V I)$ (dog lung); II) BFS + saline-buffer; $I I I)$ fraction (IV + VI) (dog lung) + borate buffer. These mixtures were incubated at $37^{\circ} \mathrm{C}$. and sampled at intervals for the usual tests of fibrinolytic activity.

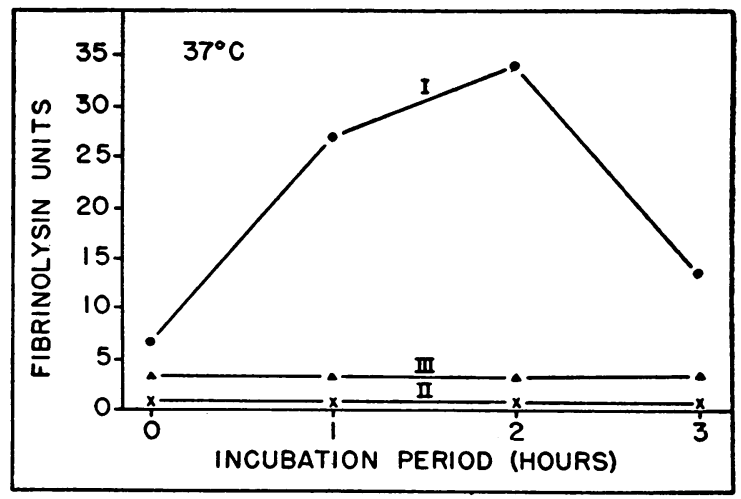

Fig. 3. Activation of Bovine Fraction I "Serum" by Dog Fibrinolysokinase (see text)

The data (Figure 3) clearly show a progressive formation of lysin in $I$, as compared with the negative results in $I I$ and $I I I$, strongly suggesting the presence of some prolysin in the "serum" (expressed fluid) from the clotted BF.

\section{RESULTS}

\section{Survey of fibrinolysokinase activity in various tissue fractions (Dog):}

Table I presents the results of an extensive survey of the various fractions of tissue obtained from dogs. Each tissue fraction was incubated with $a$ ) dog profibrinolysin and $b$ ) buffer for one hour at $29^{\circ} \mathrm{C}$. with subsequent assay of lysin. Kinase units were obtained by subtracting from the total units found in $a$ ) the sum of the units in $b$ ) and in the prolysin control. Subsequent experiments demonstrated that the one hour incubation at $29^{\circ} \mathrm{C}$. was not optimal but even the low kinase titers obtained suggest which tissues are the most potent sources of fibrinolysokinase.

, Lung and uterus (esp. during pregnancy) provide the most active fractions. One or more 
TABLE I

Survey of fibrinolysokinase activity of dog tissue fractions* Kinase units per $\mathrm{ml}$

\begin{tabular}{|c|c|c|c|c|c|c|c|c|}
\hline Fraction & I & II & III-A & III-B & IV & V & VI & VII \\
\hline $\begin{array}{l}\text { Adrenal cortex } \\
\text { Adrenal medulla } \\
\text { Artery } \\
\text { Bone marrow } \\
\text { Brain } \\
\text { Gall bladder } \\
\text { Heart } \\
\text { Intestine } \\
\text { Kidney } \\
\text { Liver } \\
\text { Lung I } \\
\quad \text { II } \\
\text { Lymph gland } \\
\text { Meninges } \\
\text { Muscle } \\
\text { Omentum } \\
\text { Ovary I } \\
\text { (Pregnant) II } \\
\text { Pancreas } \\
\text { Placenta } \\
\text { Pericardium } \\
\text { Pituitary } \\
\text { Seminal vesicles } \\
\text { Spinal cord } \\
\text { Spleen } \\
\text { Stomach } \\
\text { Testis } \\
\text { Thyroid } \\
\text { Ureter } \\
\text { Urinary bladder } \\
\text { Uterus I } \\
\text { (Pregnant) II } \\
\text { Vein } \\
\text { Erythrocytes } \\
\text { Leukocytes } \\
\text { Platelets }\end{array}$ & $\begin{array}{l}1.4 \\
0.8 \\
0.6 \\
0.8 \\
2.0 \\
2.6 \\
0 \\
1.8 \\
0.8 \\
0.8 \\
2.2 \\
4.8 \\
4.0 \\
4.8 \\
2.0 \\
0 \\
0.6 \\
1.4 \\
3.0 \\
3.3 \\
2.6 \\
1.2 \\
1.2 \\
1.2 \\
2.0 \\
0.6 \\
1.0 \\
1.0 \\
1.4 \\
2.2 \\
2.0 \\
4.0 \\
5.8 \\
3.0 \\
0.6 \\
1.0 \\
0.4\end{array}$ & $\begin{array}{l}1.4 \\
0.8 \\
0 \\
2.6 \\
0 \\
1.0 \\
0.2 \\
0.8 \\
2.6 \\
1.4 \\
0.4 \\
0 \\
Z \\
0.9 \\
3.4 \\
1.0 \\
\overline{0} \\
\overline{0} \\
0.6 \\
1.0 \\
0.8 \\
0.8 \\
1.4 \\
5.0 \\
2.2 \\
-\end{array}$ & $\begin{array}{l}0.8 \\
0.6 \\
0 \\
0.8 \\
0.4 \\
2.0 \\
0.4 \\
0 \\
0 \\
3.0 \\
1.2 \\
0.8 \\
1.0 \\
0 \\
0.4 \\
0.8 \\
3.4 \\
0 \\
1.2 \\
1.2 \\
0.8 \\
1.0 \\
1.6 \\
0.8 \\
0.6 \\
0.8 \\
2.0 \\
0.8 \\
0.6 \\
-\end{array}$ & $\begin{array}{l}0.6 \\
0.2 \\
0 \\
0 \\
1.4 \\
0.2 \\
0 \\
0 \\
4.0 \\
0.8 \\
- \\
- \\
0 \\
0.8 \\
3.2 \\
0 \\
0.4 \\
0.6 \\
0.4 \\
0.6 \\
0.4 \\
0.6 \\
0 \\
1.0 \\
0 \\
0 \\
0\end{array}$ & $\begin{array}{l}1.0 \\
0.8 \\
0 \\
2.6 \\
1.2 \\
3.0 \\
0.8 \\
0.4 \\
0.8 \\
1.0 \\
6.0 \\
7.8 \\
8.0 \\
2.6 \\
1.4 \\
0 \\
0.8 \\
1.2 \\
3.2 \\
0 \\
0.8 \\
1.6 \\
0.8 \\
1.2 \\
1.0 \\
0.8 \\
0.4 \\
0.8 \\
2.6 \\
1.2 \\
0.2 \\
0.8 \\
0\end{array}$ & $\begin{array}{l}0 \\
0.2 \\
0 \\
0 \\
0.6 \\
1.6 \\
0.4 \\
0.4 \\
0.2 \\
0 \\
3.0 \\
5.2 \\
5.4 \\
0.6 \\
0.6 \\
0 \\
0.4 \\
1.0 \\
0.6 \\
0 \\
0 \\
1.0 \\
0.2 \\
0.4 \\
1.0 \\
0.8 \\
0.8 \\
0.8 \\
0.6 \\
0.2 \\
1.0 \\
1.0 \\
0.6 \\
0 \\
- \\
Z\end{array}$ & $\begin{array}{l}0.6 \\
0 \\
0.2 \\
0.8 \\
0.8 \\
4.0 \\
0.6 \\
1.0 \\
0.6 \\
0.6 \\
3.4 \\
8.8 \\
7.4 \\
3.4 \\
1.0 \\
0 \\
0.8 \\
0.8 \\
1.2 \\
0 \\
0 \\
0.6 \\
0.4 \\
0.8 \\
1.0 \\
0 \\
1.0 \\
1.0 \\
0.6 \\
0.8 \\
0.8 \\
1.0 \\
1.8 \\
0.2 \\
0 \\
0.6 \\
0\end{array}$ & $\begin{array}{l}0 \\
0 \\
0 \\
0 \\
0.4 \\
0 \\
0 \\
0 \\
0 \\
0 \\
0.8 \\
0 \\
0 \\
0 \\
0.8 \\
0 \\
0 \\
0 \\
0 \\
0 \\
0 \\
0 \\
0.4 \\
0 \\
0.2 \\
0 \\
0.4 \\
0 \\
0 \\
0 \\
0 \\
1.0 \\
0 \\
0 \\
0 \\
0 \\
0\end{array}$ \\
\hline
\end{tabular}

* - No fraction.

0 No activity.

"good" fractions are noted with pancreas, gallbladder, ovary (with corpus luteum of pregnancy), lymph gland, placenta, urinary bladder, ureter, vein, bone-marrow, brain, spinal cord, and meninges. In general, fraction I was most active, with fraction IV and VI not far behind. Fraction VII was usually inactive.

Table II shows the fibrinolysokinase units obtained from the various dog lung fractions, and the single lung fraction (IV $+\mathrm{VI}$ ), prepared from the same lung, and compared to staphylokinase. In each case the kinase was allowed to react with the prolysin for one hour at $37^{\circ} \mathrm{C}$. The increased temperature of incubation has increased the lysin yield. The single fraction (IV + VI), which produces very marked activation, is, in relation to original lung weight, double the strength of the other fractions but actually contains less organic material (dry weight less ash weight) than fraction I.

\section{Antilysin (antifibrinolysin) and prolysin (pro- fibrinolysin) titers in tissue fractions:}

Antilysin titers of all fractions were determined, against dog serum lysin, using the technic previously described (15). Fractions VII of all tissues, even those thoroughly perfused, showed some antilysin (100-400 units/ml). Fractions I and VI frequently showed significant antilysin titers (80-200 units $/ \mathrm{ml})$, even in materials that were also active lysokinases.

Prolysin could not be detected in any of the fractions after treatment with staphylokinase.

TABLE III

Lysin units/ml obtained after incubation for one hour at $37^{\circ} \mathrm{C}$ of the three prolysins with staphylokinase, streptokinase and lung fractions VI obtained from various species

\begin{tabular}{l|c|c|c|c}
\hline \hline \multicolumn{1}{c|}{ Activators } & $\begin{array}{c}\text { Human } \\
\text { prolysin }\end{array}$ & $\begin{array}{c}\text { Dog } \\
\text { prolysin }\end{array}$ & $\begin{array}{c}\text { Bovine } \\
\text { prolysin }\end{array}$ & $\begin{array}{c}\text { Borate } \\
\text { buffer }\end{array}$ \\
\cline { 2 - 5 } Staphylokinase & 320.0 & 640.0 & 0 & 0 \\
Streptokinase & 252.0 & tr. & 0 & 0 \\
Mouse VI & 26.0 & 56.0 & 4.0 & 2.7 \\
Rat VI & 3.2 & 19.0 & 3.2 & 2.7 \\
Guinea pig VI* & 3.3 & 14.0 & 2.8 & tr. \\
Rabbit VI* & tr. & 10.8 & tr. & 0 \\
Cat VI* & 7.8 & 42.4 & 5.3 & 2.2 \\
Dog VI* & 5.4 & 42.4 & 5.7 & 2.2 \\
Human VI $\dagger$ & 18.0 & 40.0 & 11.8 & 5.2 \\
Bovine VI & 0 & tr. & tr. & 0 \\
Buff. saline & 0 & tr. & 0 & 0 \\
& & & &
\end{tabular}

* Perfused free from blood.

† Obtained at operation through the courtesy of Dr. William Sealy, Duke Medical School.

Trace (tr.) $=<0.5$ units $/ \mathrm{ml}$.

III. Fibrinolysokinase activity of fractions prepared from lungs of various animal species, as tested on human, dog, and bovine prolysins:

$A$. The centrifugally prepared tissue fractions (I-VII) from lungs of six mice, two rats, and one each of the other six animals listed in Table III were tested, under the experimental conditions stated, against prolysins prepared in the same man-

TABLE II

Fibrinolysokinase units/ml of dog lung fractions and staphylokinase

\begin{tabular}{l|c|c|c|c|c|c|c|c|c|c|}
\hline \hline Fraction: & I & II & III-A & III-B & IV & V & VI & VII & (IV + VI) & Staph. \\
\hline Units/ml & 43.6 & 3.0 & 2.4 & 2.9 & 19.2 & 5.0 & 27.6 & 2.1 & 317.6 & 900 \\
\hline
\end{tabular}


ner from sera of human, dog, and bovine origin. Streptokinase and staphylokinase tests and controls are included for comparison. The lysin units (per $\mathrm{ml}$ ) are recorded only for fractions VI, which were typical and usually the most active.

Streptokinase activated only human prolysin and the lower unitage was probably due to the deterioration after one hour at $37^{\circ} \mathrm{C}$. of the lysin, which was formed very rapidly with this activator. Staphylokinase activated human and dog prolysins. Bovine prolysin was not affected by the bacterial kinases. These facts were confirmatory of earlier work.

Mouse, cat, dog, human, and rat lung fractions showed good to fair kinase activity on all three prolysins; guinea-pig and rabbit lung were less active, and bovine lung fractions were inexplicably inactive. The controls (borate buffer instead of prolysin) showed slight but significant lytic activity, in tests with those lung fractions which showed most lysokinase activity.

$B$. The effects of temperature on the activation of the three prolysins (human, dog, bovine) are recorded in Table IV. The "activators" tested were 1) dog lung (IV + VI), 2) streptokinase, 3) staphylokinase, 4) chloroform treatment (15). The lysin unitage was determined at intervals over four hours at $37^{\circ} \mathrm{C}$., the maximum yield be-

TABLE IV

Lysin units/ml obtained from human, dog, and bovine prolysins after incubation with the various activators for optimal period at $37^{\circ} \mathrm{C}$. and for four weeks at $4^{\circ} \mathrm{C}$.

\begin{tabular}{|c|c|c|c|c|}
\hline Activator & Temp. & $\begin{array}{l}\text { Human } \\
\text { prolysin }\end{array}$ & $\underset{\text { prolysin }}{\text { Dog }}$ & $\begin{array}{l}\text { Bovine } \\
\text { prolysin }\end{array}$ \\
\hline \multirow{2}{*}{ Dog lung (IV+VI) } & $37^{\circ} \mathrm{C}$. & 16.0 & 108.0 & 6.8 \\
\hline & $4^{\circ} \mathrm{C}$ & 225.0 & 540.0 & 28.0 \\
\hline \multirow{2}{*}{ Staphylokinase } & $37^{\circ} \mathrm{C}$ & 280.0 & $600+$ & tr. \\
\hline & $4^{\circ} \mathrm{C}$ & $600+$ & $600+$ & tr. \\
\hline \multirow{2}{*}{ Streptokinase } & $37^{\circ} \mathrm{C}$ & $600+$ & tr. & tr. \\
\hline & $4^{\circ} \mathrm{C}$ & $600+$ & tr. & tr. \\
\hline \multirow{2}{*}{ Chloroform } & $37^{\circ} \mathrm{C}$. & tr. & tr. & tr. \\
\hline & $4^{\circ} \mathrm{C}$ & $\operatorname{tr} .(234)^{*}$ & tr. $(600+)^{*}$ & tr. \\
\hline \multirow{2}{*}{ Saline } & $37^{\circ} \mathrm{C}$. & tr. & tr. & tr. \\
\hline & $4^{\circ} \mathrm{C}$ & tr. $(220)^{*}$ & tr. $(600+)^{*}$ & tr. \\
\hline
\end{tabular}

* Figures in parentheses indicate values obtained after staphylokinase activation. ing recorded. At the $4^{\circ} \mathrm{C}$. temperature the activation was followed over four weeks. At the end of this period the chloroformed and control (saline) human and dog prolysins were treated with staphylokinase and warmed to $37^{\circ} \mathrm{C}$., for 20 minutes, demonstrating very considerable quantities of persisting prolysin as seen from the unitage (in parentheses) included in the tests mentioned.

Very high yields of lysin were obtained from the human prolysin with streptokinase and from the human and dog prolysins with staphylokinase, especially at the cold temperature. The dog lung lysokinase was active on all three prolysins at $37^{\circ}$ C. but the titers were increased markedly (especially with human and dog prolysins) after four weeks at $4^{\circ} \mathrm{C}$. However, at this time the values were still short of the staphylokinase maxima. No significance can be attached to the mere traces of lysis detected overnight in the other tests (including the controls).

\section{Do tissue kinases and bacterial kinases act on the same precursor of fibrinolysin?}

Dog prolysin, as prepared in the above experiments, does not activate "spontaneously" even after four weeks at $4^{\circ} \mathrm{C}$. (cf. Fig. 2). Other experiments, to be published later, show that prolysin, prepared by different techniques, e.g., isoelectric precipitation at low ionic strength, higher saturation with ammonium sulfate, etc., will activate "spontaneously," reaching maximum titer in about four weeks at $4^{\circ} \mathrm{C}$. This maximum titer is not increased by staphylokinase treatment, and it is similar to the titer obtained by staphylokinase activation of the fresh prolysin. From these observations we concluded that the same prolysin was activated by staphylokinase and by the "spontaneous" mechanism.

After dog prolysin was maximally activated by staphylokinase, no increase in titer could be obtained by treatment with lung kinase. On the other hand, after "maximal" activation with lung kinase, subsequent treatment with staphylokinase usually did produce some increase in lysin titer, but never to a value higher than that obtained by staphylokinase treatment alone.

It was therefore concluded that a single precursor (prolysin) would suffice to explain lysin 
formation by the three activation mechanisms : 1) "spontaneous" (? serum fibrinolysokinase), 2) bacterial fibrinolysokinase (e.g., staphylokinase), and 3) tissue fibrinolysokinase (e.g., lung [IV + VI]); complete activation being achieved by the first two (under appropriate experimental conditions) but only partial activation by the present preparations of lung tissue.

\section{Prolysin activation at varying dilutions of fibrinolysokinase:}

Various dilutions of dog lung fraction (IV + VI) were incubated at $37^{\circ} \mathrm{C}$. with dog prolysin and the mixtures sampled at intervals for the usual fibrinolysin assay. The results are presented graphically in Figure 4. Lysin deterioration is clearly evident beyond the peaks of the curves and undoubtedly modifies the kinetics of the activation reaction. Nevertheless, the curves differ greatly and suggest that rate, certainly, and amount, probably, of lysin formation are directly dependent upon the concentration of fibrinolysokinase.

\section{Tissue lysokinases and lysin formation in whole serum or plasma:}

The activation of prolysin in whole ( $\mathrm{dog}$ ) serum by lung fibrinolysokinase, at $37^{\circ} \mathrm{C}$., has proved disappointing, only traces of fibrinolytic activity being detectible. When serum was diluted $(\times 5)$ with saline, a fibrinolysin unitage of about 6.5 per $\mathrm{ml}$ was obtained. Considering relative dilutions $(1: 20)$ this is a significant amount of the 230 units $/ \mathrm{ml}$ simultaneously found in a prolysin prepa-

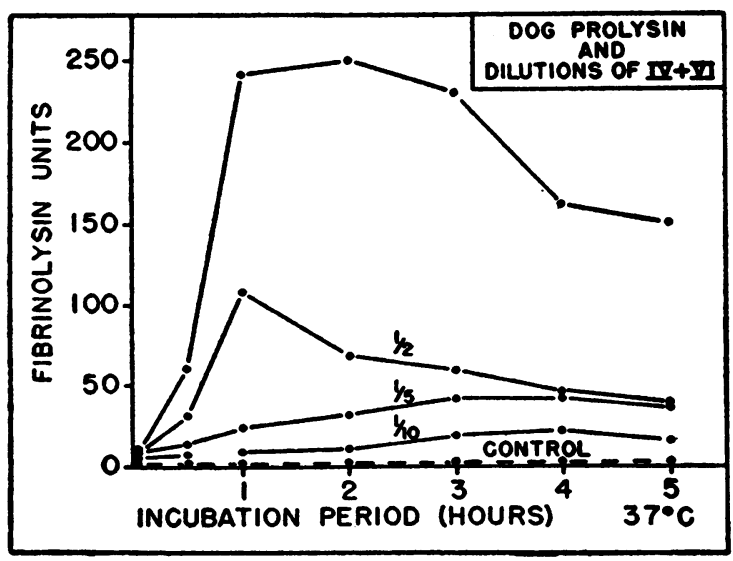

Fig. 4. Activation of Dog Prolysin by Various Dilutions of Lung Fibrinolysokinase ration (concentrated in one quarter original serum value) obtained from the same dog serum.

That prolysin in whole plasma is also poorly activated by tissue lysokinases is illustrated, incidentally, in the tests of Table VI. As stated in the footnote, the plasma clots containing dog lung fraction (IV + VI) lysed within two and a half hours, whereas the control clots were solid after 24 hours.

\section{Extraction experiments on lung fibrinoly- sokinase:}

Dog lung fraction (IV + VI) is a complex mixture in which the lysokinase factor is present in the suspended material and not demonstrable in the soluble extractive obtainable with saline. Subjecting the preparation to lipid solvents, e.g., alcohol, acetone, ether, chloroform, carbon tetrachloride, failed to yield any active extracts and the residue always retained most of its activity. The tissue fraction dried with alcohol and ether suffered only partial diminution of lysokinase potency.

\section{Stability of fibrinolysokinase:}

The lysokinase activity of dog lung fraction (IV $+\mathrm{VI})$ was destroyed by five minutes heating at $80^{\circ} \mathrm{C}$. and only slight activity remained after 30 minutes warming at $56^{\circ} \mathrm{C}$. At $37^{\circ} \mathrm{C}$. and $29^{\circ} \mathrm{C}$. potency remained unchanged for at least four hours. At $0^{\circ} \mathrm{C}$. no detectible alteration was noted in 48 hours and only slight deterioration after two weeks. Freezing and storage of the more concentrated tissue fractions at $-20^{\circ} \mathrm{C}$. showed unchanged unitage data over at least a month. Under all the above conditions, dilution appeared to be a factor in lessening the kinase stability.

\section{Blood clotting factors in tissue fibrinolyso- kinase preparations:}

In connection with the survey of various tissue fractions for lysokinase activity, many tests were run to afford at least a preliminary idea of the presence or absence of a number of factors which might be expected to participate in or modify bloodclotting reactions.

Fibrinogen: The absence of clotting on the addition of thrombin showed that no fibrinogen appeared in any of the tissue fractions. 
Thrombin: tested for by adding $0.1 \mathrm{ml}$ of tissue fraction to $0.1 \mathrm{ml}$ fibrinogen (free from prothrombin after $\mathrm{BaSO}_{4}$ adsorption). The only seemingly significant result was a 26 minute coagulation by seminal vesicle fraction I, although questionable coagulation after 12 hours was seen in a small number of other tests.

Prothrombin was considered detectible, if present (particularly in view of the thromboplastic activity of many of the tissue preparations) by simply repeating the foregoing test with the addition of $0.1 \mathrm{ml} 0.02 \mathrm{M} \mathrm{CaCl}_{2}$. Again only the seminal vesicle I clotted the fibrinogen, but the 22 minutes was not significantly different from the preceding test. In other occasional instances, some clots were observed in 12-24 hours.

That fibrinogenolysis was a factor operating to mask possible traces of thrombic (or prothrombic?) activity was evident from the finding that thrombin would no longer clot the fibrinogen in a number of the mixtures tested after a number of hours incubation with tissue fractions.

Antithrombin: tested (with appropriate controls) by incubation of the tissue fraction with a potent (bovine) thrombin. Table $\mathrm{V}$ records the results of some tests on dog lung fraction (IV + VI) which is seen markedly to weaken the thrombic activity both immediately (15 seconds) and increasingly with incubation $\left(29^{\circ}\right.$ C. $)$. In the controls, with saline, and with ordinary thromboplastin (which shows no fibrinolysokinase activity -see Table VI), the thrombin is only slightly unstable over the 30 minute incubation period. The significance of antithrombic and thromboplastic

TABLE $V$

Antithrombic action of dog lung IV + VI

\begin{tabular}{|c|c|c|c|}
\hline \multirow{2}{*}{ Incubation Period: } & \multicolumn{3}{|c|}{$\begin{array}{c}\text { Clotting time: } \\
\substack{0.25 \\
\text { ture } \\
\left(29^{\circ} \mathrm{C}\right)}\end{array}$} \\
\hline & $15^{\prime \prime}$ & $15^{\prime}$ & $30^{\prime}$ \\
\hline $\begin{array}{l}\text { Thrombin } \\
+ \\
\text { Buffered saline }\end{array}$ & $26.5^{\prime \prime}$ & $32.8^{\prime \prime}$ & $38.3^{\prime \prime}$ \\
\hline $\begin{array}{l}\text { Thrombin } \\
+ \\
\text { Lung IV + VI }\end{array}$ & $119.6^{\prime \prime}$ & $216.0^{\prime \prime}$ & $250.0^{\prime \prime}$ \\
\hline $\begin{array}{l}\text { Thrombin } \\
+ \\
\text { Thromboplastin }\end{array}$ & $24.0^{\prime \prime}$ & $28.6^{\prime \prime}$ & $31.6^{\prime \prime}$ \\
\hline
\end{tabular}

TABLE VI

Separation of fibrinolysokinase and thromboplastin

\begin{tabular}{|c|c|c|}
\hline Reagents & $\underset{\text { time }}{\text { Plasma clotting }}$ & $\begin{array}{c}\text { Prolysin activation } \\
\text { lysis time }\end{array}$ \\
\hline $\begin{array}{l}\text { Buffered saline } \\
\text { Thromboplastin } \\
\text { Staphylokinase }\end{array}$ & $\begin{array}{c}\text { seconds } \\
127.0 \\
8.4 \\
200.0^{*}\end{array}$ & $\begin{array}{c}\text { minutes } \\
\text { No lysis five hours } \\
\text { No lysis five hours } \\
\frac{1}{\frac{1}{4}}\end{array}$ \\
\hline $\begin{array}{l}\text { Lung IV + VI } \\
\text { Lung IV + VI, } \\
\text { boiled } 3 \text { min. }\end{array}$ & $\begin{array}{l}13.0^{*} \\
18.5\end{array}$ & $\stackrel{3}{\text { No lysis five hours }}$ \\
\hline $\begin{array}{c}\text { Lung IV + VI } \\
+ \\
\text { buffered saline } \\
\text { Lung IV + VI } \\
+ \\
\text { heparin } 0.25 \mathrm{mg} / \mathrm{ml}\end{array}$ & $\begin{array}{l}13.4^{*} \\
\infty \dagger\end{array}$ & $\begin{array}{l}4 \frac{1}{3} \\
7\end{array}$ \\
\hline
\end{tabular}

* Plasma clots lysed by two and a half hours.

† At two and a half hours no clot after addition strong thrombin, suggesting fibrinogenolysis.

$\ddagger$ Lysis time of 1 per cent fibrin clot containing prolysin + activator (preincubated one hr. at $37^{\circ} \mathrm{C}$ ).

(see below) activities in the same tissue preparation must be emphasized.

Antithromboplastin: Observations that dilution of lung (IV + VI) decreased rather than increased plasma clotting times argue against any readily demonstrable "antithromboplastin."

Thromboplastin: The anticipated finding of considerable thromboplastic activity in many of the tissue fractions was simply demonstrated by the plasma prothrombin time test of Quick (18), merely substituting the various tissue fractions for the usual thromboplastin. A single specimen of oxalated dog plasma, kept frozen at $-20^{\circ} \mathrm{C}$. between test runs, was used throughout the comparative survey. The simple recalcification time of this plasma was 120 seconds and the prothrombin clotting time, with Schieffelin's "horse tissue" thromboplastin, was $8.4 \mathrm{sec}$. Tissue fractions giving prothrombin times (in parentheses) of 15 seconds or less include: brain I $\left(12.5^{\prime \prime}\right)$, II $\left(11.9^{\prime \prime}\right)$, IV $\left(15^{\prime \prime}\right)$; spinal cord I $\left(10.9^{\prime \prime}\right)$; lymph gland I $\left(12.4^{\prime \prime}\right)$, II $\left(14.0^{\prime \prime}\right)$, IV $\left(12.5^{\prime \prime}\right)$, V $\left(14.0^{\prime \prime}\right)$; intestine I $\left(12.2^{\prime \prime}\right)$, II $\left(14.3^{\prime \prime}\right)$, IV

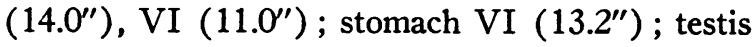
I $\left(12.0^{\prime \prime}\right)$, II $\left(15.0^{\prime \prime}\right)$; kidney IV $\left(14.5^{\prime \prime}\right)$; lung I $\left(12.8^{\prime \prime}\right)$, IV $\left(15.0^{\prime \prime}\right)$; uterus VI $\left(15.0^{\prime \prime}\right)$. Tests were not run on placenta.

The chosen method designedly demonstrates only the more powerful thromboplastins, sometimes acting despite the presence also of consider- 
able inhibitors (see antithrombin). For purposes of the survey, a prothrombin time of longer than 40 seconds was regarded as indicating no significant amount of thromboplastic activity. This was the finding with: all fractions VII; all fractions of thyroid, muscle, liver, bone-marrow, platelets, leucocytes, erythrocytes. Pancreas fractions VI and VII, although not markedly fibrinolytic, prolonged the clotting times to many minutes in these tests.

Experimental separation of thromboplastic and fibrinolysokinase activity of tissue fractions: Since the potent thromboplastin preparation used in these studies showed no measurable fibrinolysokinase activity, while the staphylokinase lacked thromboplastic activity, it is probable that the frequent occurrence of the two kinds of activators in the same tissue fraction is merely coincidental, in which case an experimental separation should be possible. The experiments summarized in Table VI show that this may be accomplished by taking advantage of 1 ) the greater thermolability of the lysokinase and 2) the sensitivity of the thromboplastin to inhibition by heparin. All the above points are clearly brought out in the data of the Table.

\section{DISCUSSION}

The evidence of the survey tests reported in this study supports the conclusion that a fibrinolysokinase (factor which converts serum profibrinolysin into active fibrinolysin) is quantitatively demonstrable in materials obtained by differential centrifugation from a wide variety of tissues. Lung is a potent source and convenient as to amount available and ease of exsanguinating by perfusion. The data of Table I show fibrinolysokinase to be ubiquitous, in very varying amounts in a great many tissues and fractions. Only fractions VII usually give a negative result. The most significant concentration appears to be in the small particle fractions IV and VI, corresponding to Claude's "large granules" and "microsomes," and confirming, to some extent, Tagnon's findings on rat lung.

Lack of real species specificity is indicated in the data on lung fractions VI in Table III, in which tests were made with prolysins of human, dog, and bovine origin, all of which were moderately activated by mouse, cat, dog, and human lung lysokinase and slightly by guinea-pig and rabbit preparations. The lack of activity of bovine lung fractions for all three prolysins is unexplained.

Although tissue lysokinase, in the relatively impure form studied, does not activate (dog) profibrinolysin to as great an extent as does staphylokinase, the evidence (Section IV) indicates a common prolysin able to yield a similar fibrinolysin with the several types of activator. The prolysin in the present experiments is not subject to "spontaneous" activation or to activation by treatment with chloroform (Table IV). This is distinctly different from other prolysin preparations (Section IV) and raises new questions as to a probable "serum lysokinase" which has apparently been removed in the present method of fractionation. Further experiments are in progress on this question.

Tissue lysokinases, like staphylokinase (but differing from streptokinase [12]), require a considerable time to effect maximal activation of prolysin. This time factor is modified by a number of variables, including temperature, strength of kinase, etc., and the fibrinolysin yield is altered also by deterioration and by the action of antifibrinolysin, if present. The last may account for the difficulties encountered in using tissue kinase on whole serum or plasma, especially undiluted, as compared with the good lysin production from our purified (stable and antilysin-free) prolysins.

Dog lung fraction (IV + VI) is found to be relatively heat labile. It is well preserved in the frozen state at $-20^{\circ} \mathrm{C}$. and reasonably stable at refrigerator temperatures. At room or body temperatures it activates prolysin rapidly, while at $4^{\circ}$ C. the activation, though slow, continues for several weeks. The tissue fraction is complex and has so far resisted efforts to purify the lysokinase by extraction with saline and phosphate buffers $(\mathrm{pH}$ : 4.85-9.5), etc.

Antifibrinolysin (? from residual blood) occurs in many of the tissue fractions, although fibrinolysokinase may also be detected, e.g., fractions VI. No evidence for any antifibrinolysokinase could be obtained by dilution of dog lung fraction (IV + VI).

The crude tissue fractions contain factors which participate in or modify blood-clotting reactions in experimental systems. Fibrinogenolysis and fibrinolysis are encountered in mixtures when ac- 
tive fibrinolysin appears and the extent to which this protease may interfere with the various protein factors of the clotting system raises a number of questions which we shall not go into here. Antithrombic activity may interfere, to a minor extent, by causing difficulties in obtaining a "standard" clot for fibrinolysin assay. In lung fraction $(\mathrm{IV}+\mathrm{VI})$ a potent antithrombin is demonstrable although the tissue preparation is also strongly thromboplastic. The thromboplastic activity found in the tissue survey was almost completely restricted to the particulate fraction, although not confined to any one fraction (cf. "thromboplastic protein" of Chargaff [14]). This thromboplastic activity is almost as ubiquitous and variable (quantitatively) as the fibrinolysokinase activity but no significant correlation in distribution could be found between the two. The experiments of Table VI confirm the expectation that thromboplastic and fibrinolysokinase activities are probably independent, despite frequent co-existence of these two factors in crude tissue fractions.

\section{CONCLUSIONS}

A fibrinolytic technic, previously employed for assay of fibrinolysin and antifibrinolysin, is slightly modified to increase its range of sensitivity and to permit adaptation to a quantitative study of the fibrinolysokinase activity of certain tissue extracts. The present data offer a survey of a large number of animal tissues, fractionated by differential centrifugation, and indicate a widespread distribution of this factor, with lung, uterus, and a number of other tissues giving good yields of kinase activity. The "large granule" and "microsome" (Claude) fractions particularly show this activity, and it is not extractible with ordinary solvents. A lung fraction (IV + VI) was selected for some detailed studies.

The tissue lysokinase is relatively heat labile and best preserved frozen at $-20^{\circ} \mathrm{C}$. It requires time for maximal effect on profibrinolysin and the rate of activation and final fibrinolysin yield are modified by temperature, strength of kinase, deterioration of formed lysin, and by antilysin, if present. Serum and plasma are activated by tissue lysokinase with difficulty but dilution lessens the "antilytic" effect. Antilysin is also demonstrable in some tissue fractions.
Lung fractions from eight animal species showed quantitative differences but no real species specificity for prolysins of three (human, dog, bovine). The successful activation (? partial) of bovine profibrinolysin is noteworthy, in view of previous inability to find a bacterial activator.

The crude tissue preparations often contain factors which act on blood-clotting mechanisms, especially thromboplastin and antithrombin. Thromboplastic and fibrinolysokinase activities are experimentally separable.

\section{BIBLIOGRAPHY}

1. Fleisher, M. S., and Loeb, L., On tissue fibrinolysins. J. Biol. Chem., 1915, $21,477$.

2. Christensen, L. R., Streptococcal fibrinolysis: a proteolytic reaction due to a serum enzyme activated by streptococcal fibrinolysin. J. Gen. Physiol., 1945, 28, 363.

3. Christensen, L. R., and MacLeod, C. M., A proteolytic enzyme of serum: characterization, activation, and reaction with inhibitors. J. Gen. Physiol., 1945, 28, 559.

4. Milstone, H., A factor in normal blood which participates in streptococcal fibrinolysis. J. Immunol., 1941, 42, 109.

5. Astrup, T., and Permin, P. M., Fibrinolysis in the animal organism. Nature, 1947, 159, 681.

6. Permin, P. M., Properties of fibrinokinase-fibrinolysin system. Nature, 1947, 160, 571.

7. Tagnon, H. J., and Petermann, M. L., Activation of proplasmin by a tissue fraction. Proc. Soc. Exper. Biol. \& Med., 1949, 70, 359.

8. Claude, A., Fractionation of mammalian liver cells by differential centrifugation; problems, methods and preparation of extract. J. Exper. Med., 1946, 84, 51. Fractionation of mammalian liver cells by differential centrifugation; experimental procedures and results. Ibid., 61.

9. Lewis, J. H., Ferguson, J. H., and Jackson, B. G., Bacterial activators (lysokinases) of the fibrinolytic enzyme system of serum. Proc. Soc. Exper. Biol. \& Med., 1949, 72, 703.

10. Ferguson, J. H., Travis, B. L., and Gerheim, E. B., Fibrinogenolytic demonstration of activation and inhibition of tryptase in plasma protein fraction-I ("antihemophilic globulin"). Proc. Soc. Exper. Biol. \& Med., 1947, 64, 285.

11. Gerheim, E. B., Ferguson, J. H., Travis, B. L., Johnston, C. L., and Boyles, P. W., Staphylococcal fibrinolysis. Proc. Soc. Exper. Biol. \& Med., 1948, 68, 246.

12. Gerheim, E. B., and Ferguson, J. H., Species reactivity to staphylokinase. Proc. Soc. Exper. Biol. \& Med., 1949, 71, 261. 
13. Tagnon, H. J., and Petermann, M. L., A proplasmin activator from mammalian tissue. J. Clin. Invest., 1949, 28, 814.

14. Chargaff, E., Cell structure and the problem of blood coagulation. J. Biol. Chem., 1945, 160, 351.

15. Lewis, J. H., and Ferguson, J. H., Studies on a proteolytic enzyme system of the blood. I. Inhibition of fibrinolysin. J. Clin. Invest., 1950, 29, 486.

16. Guest, M. M., Ware, A. G., and Seegers, W. H., A quantitative study of antifibrinolysin in chick plasma: increase in antifibrinolysin activity during pteroylglutamic acid deficiency. Am. J. Physiol., 1947, 150, 661.

17. Ware, A. G., Guest, M. M., and Seegers, W. H., Fibrinogen: with special reference to its preparation and certain properties of the product. Arch. Biochem., 1948, 13, 231.

18. Quick, A. J., The Hemorrhagic Diseases and the Physiology of Hemostasis. Charles C. Thomas, Springfield, Ill., 1942. 